\title{
Buku Pengembangan Diri sebagai Media Art as Therapy (Studi Kasus: Buku "Nanti Kita Cerita Tentang Hari Ini”)
}

\author{
Yulianti Mayank Sari \\ Magister Desain, Fakultas Seni Rupa dan Desain, Institut Teknologi Bandung, \\ J1 Ganesha No.10, Bandung \\ yuliantimygs@gmail.com \\ Riama Maslan Sihombing \\ Magister Desain, Fakultas Seni Rupa dan Desain, Institut Teknologi Bandung, \\ Jl Ganesha No.10, Bandung \\ Irma Damajanti \\ Magister Desain, Fakultas Seni Rupa dan Desain, Institut Teknologi Bandung, \\ Jl Ganesha No.10, Bandung
}

\begin{abstract}
Abstrak
Bidang seni rupa dan desain tidak hanya sebatas pada aspek estetik, bila digali lebih dalam sebuah karya seni rupa dan desain memiliki manfaat pada aspek psikologis. Filsuf Alain de Botton mengatakan bahwa seni memiliki efek terapeutik dengan memanfaatkan kelemahan psikologis manusia dan menjadikannya sebagai kekuatan, yaitu remembering, hope, sorrow, rebalancing, self-understanding, growth, dan appreciation yang memiliki rmanfaat pada kesehatan mental. Buku 'Nanti Kita Cerita Tentang Hari Ini' atau disingkat 'NKCTHI' dijadikan studi kasus dalam menganalisis buku pengembangan diri bergambar sebagai media art as therapy. Pendekatan deskriptif kualitatif digunakan sebagai metode dalam membedah buku tersebut. Teknik pengumpulan data dilakukan dengan studi literatur terkait dan observasi baik offline maupun online. Studi literatur yang digunakan beracuan pada teori Art as Therapy oleh Alain de Botton (2013). Tujuan dari penelitian ini adalah untuk membuktikan apakah teori tersebut dapat diterapkan pada buku NKCTHI. Dapat disimpulkan bahwa hasil observasi pembaca buku NKCTHI memenuhi aspek-aspek terapeutik sebagai media art as therapy.
\end{abstract}

Kata kunci : art as therapy, buku pengembangan diri, desain visual

\section{Pendahuluan}

Desain merupakan bagian yang tidak terpisahkan dalam kehidupan sehari-hari pada masyarakat dewasa ini. Hubungan manusia dan desain akan semakin beriringan, selain fungsi estetik desain juga berfungsi dalam memudahkan kehidupan manusia. Desain dalam pengertian visual (keseni-rupaan) memiliki tiga bidang utama yaitu Desain Komunikasi Visual (Desain Grafis), Desain Produk dan Desain In- terior (Sarwono \& Lubis, 2007:4). Definisi masyarakat umum pada bidang seni rupa dan desain masih terbatas dengan nilai estetika yang terlihat dipermukaan, sehingga objek dari suatu karya seni dan desain dianggap sebagai sesuatu yang menghibur, sebuah aksesoris, dan hal-hal yang hanya dinikmati secara visual. Asumsi tersebut tidaklah salah, namun bidang seni rupa dan desain tidak sebatas pada fungsi estetika dan 
nilai-nilai praktis saja. Pada aspek psikologis, seni rupa dan desain mampu mempengaruhi manusia secara emosional. Menurut Alain de Botton, seni memiliki efek terapeutik atau terapi bagi penikmatnya dengan memanfaatkan kelemahan psikologis manusia dan mengubahnya menjadi sumber kekuatan yang bermanfaat pada kesehatan mentalnya.

Buku pengembangan diri atau self help book merupakan cara mudah untuk mendapatkan efek terapeutik dalam seni. Buku pengembangan diri bertujuan untuk membentuk pola pikir dan memberikan solusi pada suatu permasalahan, buku tersebut dibuat berdasarkan fakta dan pengalaman. Buku pengembangan diri banyak ditemukan di berbagai toko buku dengan tema dan judul beragam, namun buku pengembangan diri yang populer didominasi oleh terbitan luar negeri dan didominasi teks di dalamnya. Sejak kemunculan buku \#88 Love Life di tahun 2016 sebagai buku pengembangan diri lokal terlaris yang didominasi ilustrasi, dengan penjualan mencapai 40.000 eksamplar, buku pengembangan diri berupa kutipan dengan ilustrasi mulai banyak bermunculan di toko buku Indonesia, seperti Journal of Gratitude dan Daily Dose of Shine. Buku pengembangan diri jenis ini banyak diminati oleh kalangan remaja hingga dewasa karena terdapat ilustrasi yang menarik sehingga ringan dan mudah dibaca. Pada akhir 2018 penjualan buku \#88 Love Life dikalahkan oleh buku pengembangan diri best seller yang fenomenal saat ini yaitu 'Nanti Kita Cerita Tentang Hari Ini' atau disingkat 'NKCTHI' karya Marchella F.P. dengan penjualan 77.000 eksemplar hingga bulan Februari 2019. Buku ini merupakan flash fiction yang dibuat berdasarkan kumpulan pengalaman banyak orang dengan penggalan kutipan-kutipan yang dekat dengan kehidupan sehari-hari. Sebelum buku NKCTHI terbit, terdapat akun instagram NKCTHI yang sudah memiliki banyak pengikut dan aktif membuat konten dan berinteraksi dengan para followers-nya, hal ini merupakan cara penulis buku NKCTHI dalam menggali materi untuk konten buku dengan cara berinteraksi dengan calon pembacanya, sehingga banyak pembaca buku NKCTHI merasa relevan dengan isi buku tersebut.

Berbagai respon banyak diterima dari pembaca buku NKCTHI, sehingga fenomena buku tersebut sangat tepat untuk dianalisis apakah terdapat efek terapeutik atau terapi pada buku NKCTHI sebagai media art as therapy. Temuan dari penelitian ini akan bermanfaat bagi para calon desainer terutama para mahasiswa baru seni rupa dan desain dalam proses perancangan karya seni dan desain, bahwa terdapat aspek-aspek lain yang perlu dipertimbangkan seperti aspek psikologis dalam berkarya.

\section{Metode Penelitian}

Buku NKCTHI dijadikan studi kasus dalam menganalisis buku pengembangan diri bergambar sebagai media art as therapy. Pendekatan deskriptif kualitatif digunakan sebagai metode dalam membedah buku tersebut. Teknik pengumpulan data dilakukan dengan studi literatur terkait dan observasi baik offline maupun online. Studi literatur yang digunakan beracuan pada teori Art as Therapy oleh Alain de Botton (2013). Observasi secara online dilakukan untuk mengumpulkan data dan informasi terkait buku NKCTHI dan mengumpulkan berbagai respon pembaca buku NKCTHI baik di media sosial dan website seperti goodreads.com. Observasi secara offline dilakukan dengan melihat respon dan reaksi lingkungan terdekat ketika membaca buku tersebut. Dengan berbagai respon dan tanggapan yang diperoleh akan dihubungkan dengan teori art as therapy apakah buku NKCTHI memiliki efek terapeutik atau terapi. 

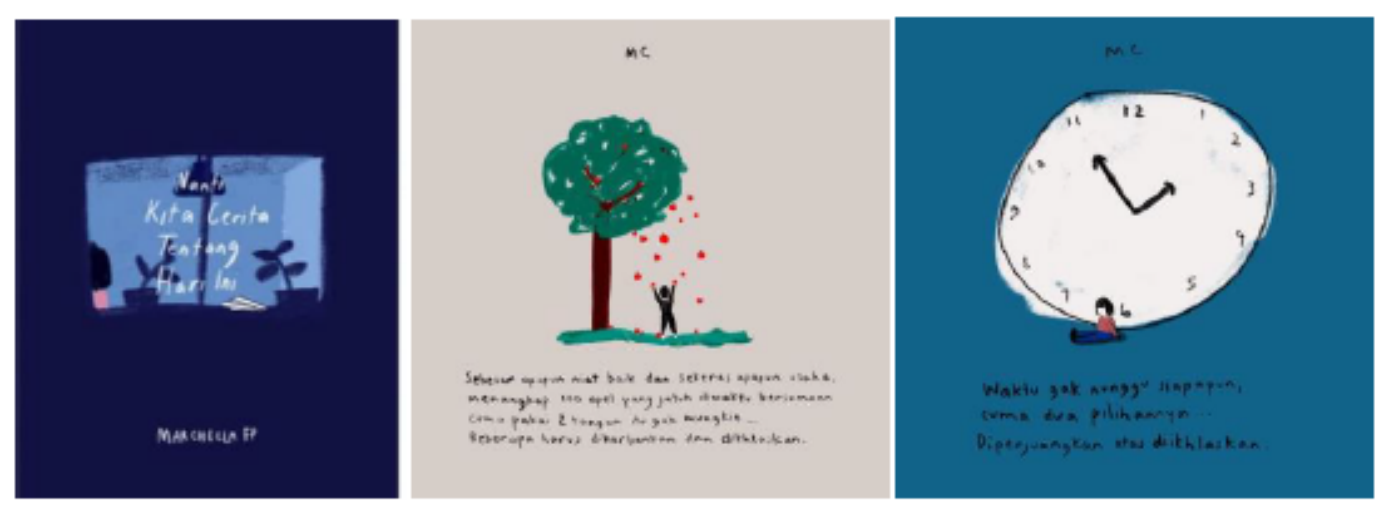

Gambar 1 Cover dan Konten Buku NKCTHI

\section{Hasil dan Pembahasan}

Dalam mendeskripsikan hasil penelitian secara sistematis, pada bagian hasil dan pembahasan akan dibagi dengan 3 sub bab. Pertama akan dibahas mengenai buku NKCTHI dan isi konten di dalamnya, termasuk sosial media yang digunakan seperti instagram dan YouTube. Selanjutnya akan dijabarkan beberapa respon pembaca buku NKCTHI yang telah dipilih secara acak untuk mewakili keseluruhan pembaca. Sub bab terakhir mengenai hubungan buku NKCTHI sebagai media art as therapy, dimana peneliti telah menganalisis isi konten buku NKCTHI dan juga mengobservasi berbagai respon pembaca buku NKCTHI secara online untuk melihat apakah terdapat efek terapeutik atau terapi pada buku NKCTHI.

\subsection{Buku NKCTHI}

'Nanti Kita Cerita Tentang Hari Ini' atau yang biasa dikenal dengan NKCTHI termasuk dalam jenis novel flash fiction karangan Marchella F.P, yang merupakan penulis sekaligus illustrator dari buku tersebut. Marchella F.P telah menerbitkan dua buku yang juga best seller yaitu Generasi 90an (2013) dan Generasi 90an: Anak Kemaren Sore (2015). Buku NKCTHI masuk ke dalam kategori self improvement atau buku pengembangan diri dengan Kepustakaan Populer Gramedia sebagai penerbitnya. Buku ini dapat dinikmati oleh pembaca 34 dari usia 13 tahun keatas. Buku ketiga yang dibuat oleh Marchella F.P ini dibuat kurang lebih selama 2 tahun sejak 2016, dan terbit di bulan Oktober 2018.

Buku NKCTHI memiliki empat babak yang berisi penggalan-penggalan kalimat pendek yang bertujuan sebagai pengingat dalam menjalani kehidupan sehari-hari. Tokoh dalam buku ini adalah Awan, seorang wanita yang menyadari bahwa setelah 27 tahun menjalani kehidupannya, banyak hal berubah seiring berjalannya waktu. Sebagai contoh, waktu bercerita Awan dan Ibunya semakin sedikit dan cara pandang mereka pun semakin berlawanan, tapi tentu saja seorang anak tidak ingin menyakiti hati ibunya. Awan takut melupakan prinsip-prinsip yang ia pegang saat ini ketika kelak ia semakin dewasa, sehingga sejak saat itu Awan bertekad untuk mengirim surat untuk anaknya di masa depan. Agar Awan dapat terus mengingat tentang hari ini: "Tentang memori, gagal, tumbuh, patah, bangun, hilang, menunggu, bertahan, berubah, dan semua ketakutan manusia pada umumnya". 


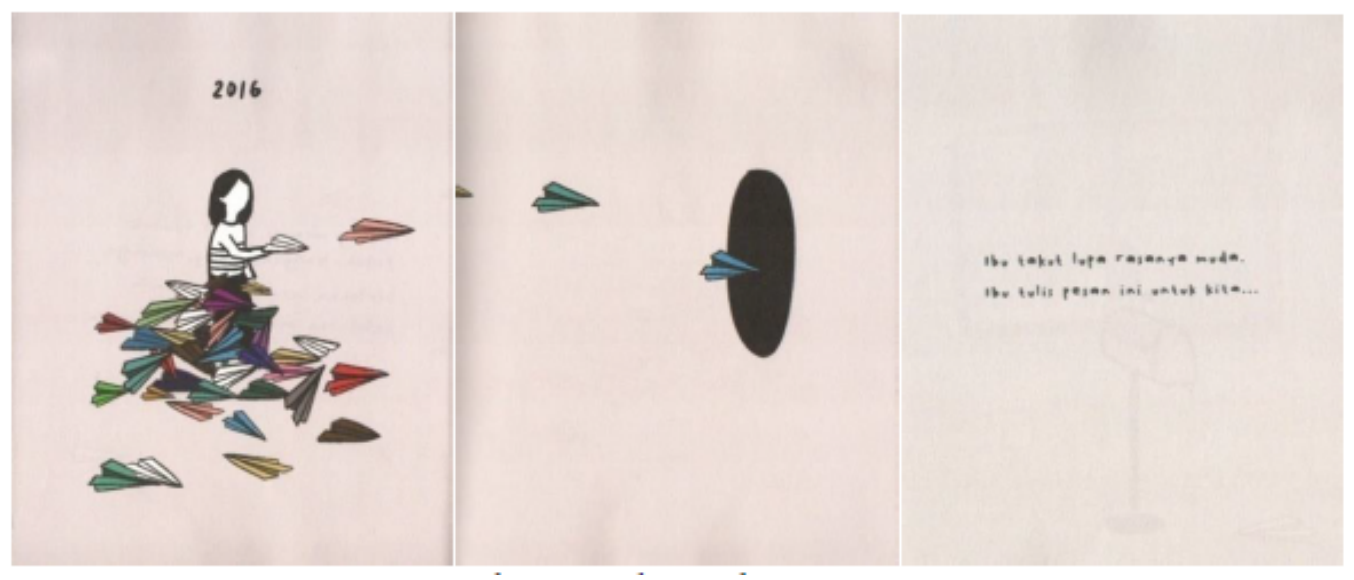

Gambar 2 Prolog Buku NKCTHI

Babak cerita dalam buku NKCTHI yang berisi potongan-potongan kalimat (quotes) dengan ilustrasi sederhana, adalah babak pagi, siang, sore, dan malam. Walaupun tidak memiliki alur yang saling berhunungan di tiap babaknya, namun kalimat dalam buku tersebut merupakan penggalan pesan-pesan yang ingin Awan ingat atas berbagai pengalaman hidup dan proses pembelajaran yang telah dilaluinya. Di akhir cerita, Awan mengatakan keresahannya akan lupa dan mengecewakan orang-orang di masa depan, sehingga segala keresahannya sudah terekam dalam kumpulan surat. Awan bercerita tentang putrinya yang sudah berusia 27 tahun dan akan segera menikah. Tujuh hari sebelum ikrar diucapkan, Awan memiliki kesempatan untuk menebus banyak malam yang tertunda untuk bercerita. Tentang segala hal yang menjadi ketakutan dan keresahan manusia pada umumnya. "Nanti kita cerita tentang hari ini, besok kita buat yang lebih baik lagi". Cerita NKCTHI pada umumnya hampir dirasakan semua orang, sehingga orang yang memiliki kesamaan dalam masalah yang sedang atau pernah dihadapi akan merasa tersentil dan dapat beranggapan bahwa mereka tidak sendiri. Buku ini mengajarkan kita untuk menerima dan menjalani saja hidup sebagaimana mestinya. Di saat senang maupun sedih, jatuh dan bangun merupakan hal yang wajar dialami oleh manusia. Sehingga setelah 'menyentil' kita dalam suatu permasalahan yang biasa dihadapi, penulis mencoba memberikan solusi yang rasional untuk 'menyadarkan' kita yang kurang sensitif ataupun terlalu sensitif. Agar lebih berlapang dada, bersyukur, memberi, dan meredam ego kita sebagai manusia. Karena biasanya masalah diciptakan dalam pikiran sendiri, dan cara mengatasinya hanya dalam bagaimana kita menyikapi masalah tersebut.

Sebelum buku NKCTHI terbit, Marchella sudah membuat akun instagram @nkcthi sejak Februari 2018 sebagai bahan riset atas tulisan-tulisan yang sudah ia buat. Instagram@nkcthi berisi quotes mengenai kehidupan yang dilengkapi dengan ilustrasi yang nantinya akan menjadi bagian dari buku NKCTHI. Akun@nkcthi banyak membuat pertanyaan di instastory mengenai permasalahan kehidupan sehari-hari. Sehingga buku NKCTHI dibuat berdasarkan kumpulan pengalaman banyak orang maupun hasil observasi dan pengalaman pribadi penulis, yang berangkat dari a quarter life crisis (krisis hidup seperempat abad) yang banyak dialami oleh kaum milenials maupun generasi $\mathrm{Z}$ yang berusia 20-30 tahun keatas. Akun instagram @nkcthi mendapat respon yang sangat positif, melebihi akun instagram pribadi sang penulis. Hingga saat 
Yulianti Mayank Sari, Riama Maslan Sihombing, Irma Damajanti,

Buku Pengembangan Diri sebagai Media Art as Therapy (Studi Kasus: Buku "Nanti KitaCerita Tentang Hari Ini")

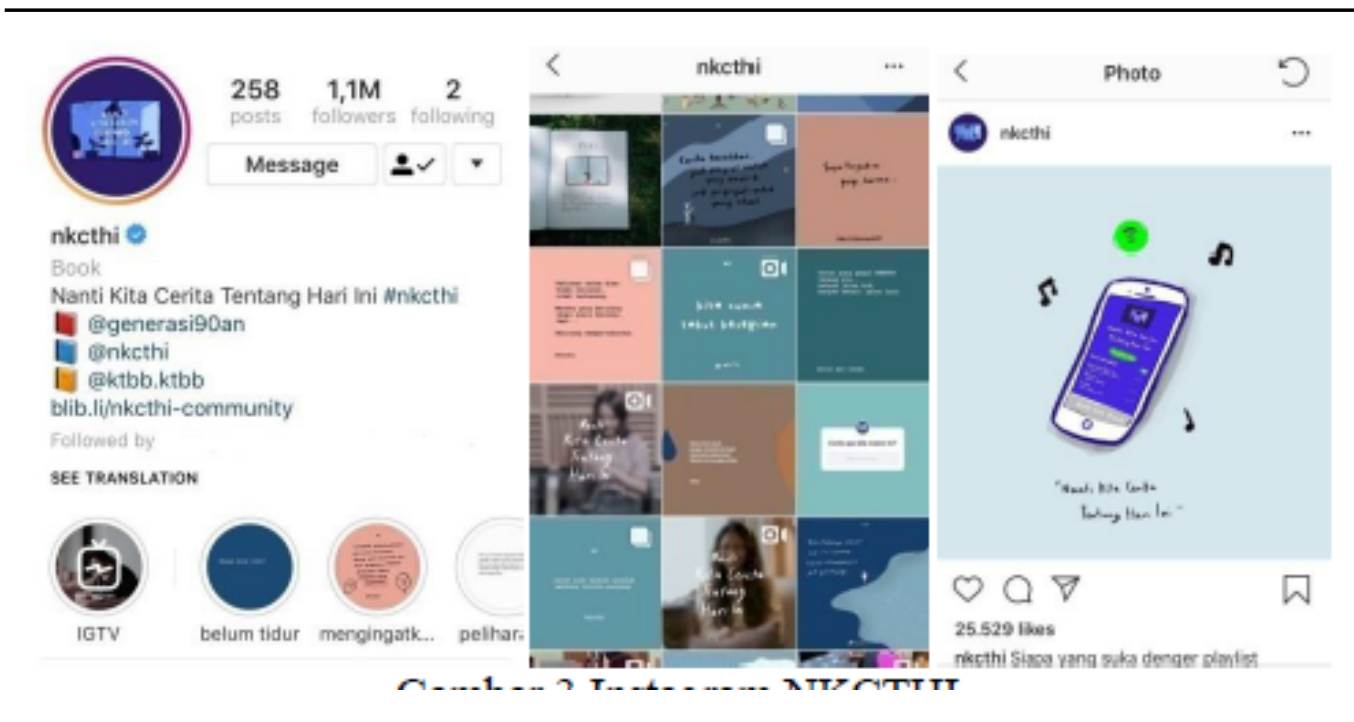

Gambar 3 Instagram NKCTHI

ini, followers akun instagram@nkcthi sudah mencapai $1.1 \mathrm{~m}$. Tak heran jika pre-order pertama buku NKCTHI terjual hanya dalam waktu 2 menit sebanyak 500 eksemplar, disusul dengan pre-order kedua sebanyak 4.000 eksemplar dalam waktu 7 menit. Kemudian pre-order ketiga terjual sebanyak seribu eksemplar hanya dalam waktu semalam. Hingga saat ini buku NKCTHI telah memasuki cetakan ke-11 dan terjual sebanyak 77.000 eksemplar hingga bulan Februari 2019.

Pada awal penulisan buku NKCTHI, Marchella F.P. membuat playlist lagu yang menerjemahkan ruang atau suasana yang dibayangkan di dalam buku. Sehingga setelah buku NKCTHI terbit, Marchella F.P. menganjurkan untuk membaca buku sambil mendengarkan playlist yang sudah di share Marchella di akun instagram @ nkcthi melalui playlist spotify yang telah dibuat, agar 'feel' saat membaca buku tersebut dapat tersampaikan kepada pembaca. Selain instagram akun@nkcthi, Marchella juga membuat akun YouTube Nanti Kita Cerita Tentang Hari Ini. Konten yang disajikan pada YouTube channel tersebut, berisi sebuah rekaman pada saat pertama kali disodorkan buku NKCTHI untuk dibaca pada saat itu juga sambil mendengarkan playlist lagu NKCTHI sehingga kita dapat melihat respon dan reaksi mereka disaat membaca buku NKCTHI. Responden dalam konten YouTube 'Nanti Kita Cerita Tentang Hari Ini' merupakan para public figure dari artis, penyanyi hingga influencer, seperti Afgan, Dewi Sandra, Andien, Ariel, Gamaliel, Sarah Deshita, Teddy Adhitya, Kunto Aji, Naya Anindita, Eva Celia dan Leona Agustine.

\subsection{Respon Pembaca Buku NKCTHI}

Buku NKCTHI menjadi fenomenal karena antusiasme pembaca setelah membaca bukunya. Banyak yang emosional hingga tak jarang pembaca yang menangis ketika membaca buku NKCTHI. Sebagai contoh nyata, para public figure yang diberikan buku NKCTHI untuk dibaca pertama kalinya, kebanyakan dari mereka menitikkan air mata. Biasanya pada kutipan yang memiliki hubungan yang pernah atau sedang dialami oleh pembacanya, sehingga mereka menjadi emosional. Banyaknya komentar positif dari para pembaca dunia maya, menjadikan banyak orang yang belum mengetahui tentang buku NKCTHI menjadi penasaran sehingga kepopuleran buku ini tidak hanya dari media social, tapi dari mulut ke mulut. Biasanya seseorang yang sudah membaca buku NKCTHI, akan merekomendasikan buku tersebut kepada teman lainnya. Walau- 


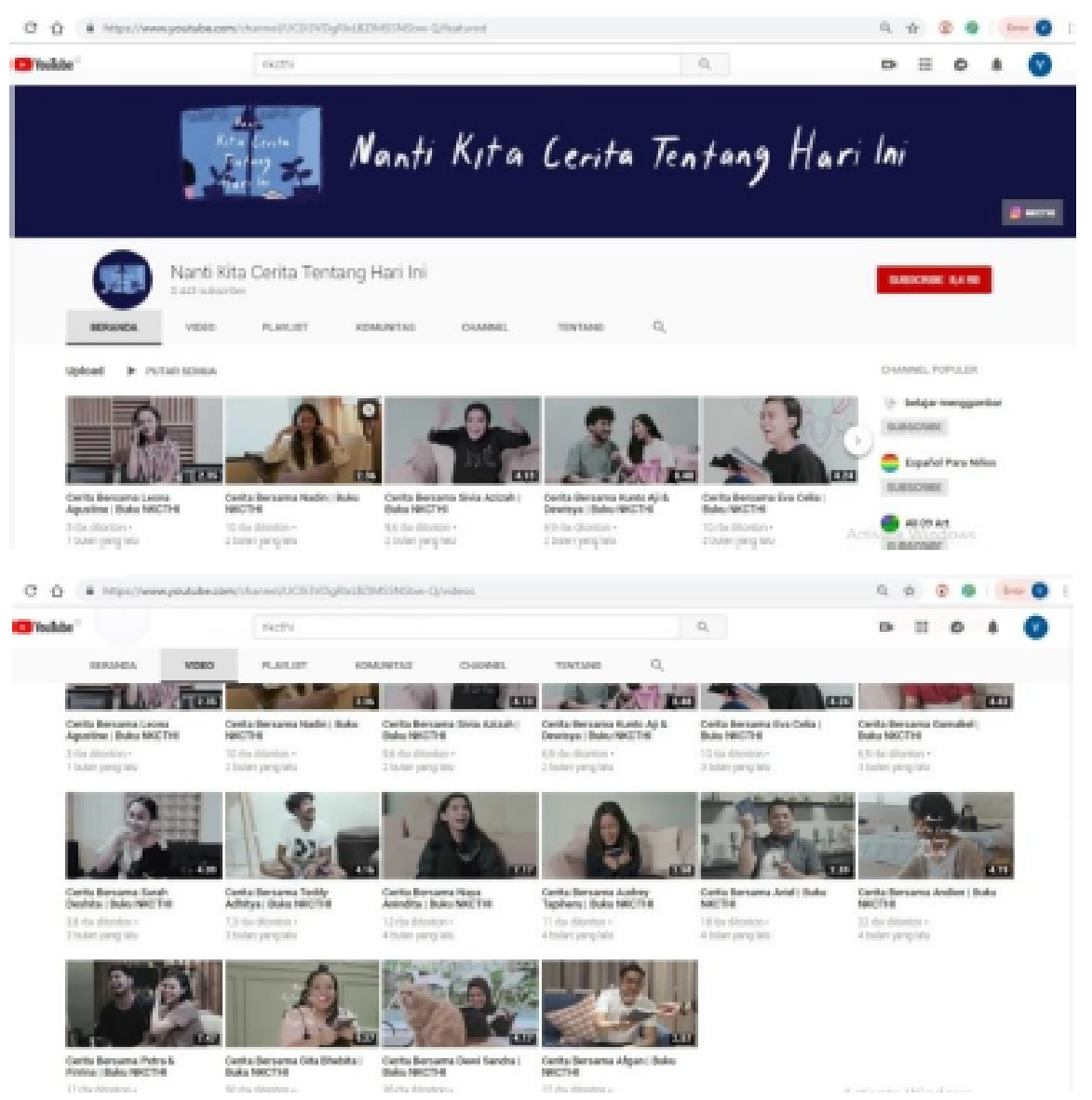

Gambar 4 YouTube NKCTHI

pun tak jarang penggemar buku NKCTHI yang memang karena sudah menyukai konten awal instagram @nkcthi yang berisi potongan dari kutipan-kutipan buku NKCTHI. Kehebohan buku NKCTHI, seperti pada saat pertama kali terbit di Gramedia dimana antrian pembeli buku NKCTHI yang sangat panjang, padahal sebelumnya sudah ada tiga kali pre-order di media sosial. Dan sempat buku NKCTHI langsung habis di seluruh Gramedia di Indonesia, hingga menunggu cetakan selanjutnya untuk di-distribusikan kembali. Sehingga tak heran jika banyak yang 'ikut' penasaran buku seperti apakah NKCTHI. Selain komentar positif, banyak juga penggemar konten dari instagram @ nkcthi yang kecewa terhadap bukunya yang tidak sesuai ekspektasi mereka. Kebanyakan dari mereka berharap bahwa buku NKCTHI akan lebih dari apa yang ditawarkan dalam konten instagram@nkcthi, terlebih harga yang ditawarkan buku ini terbilang mahal dibanding novel biasa pada umumnya. Selain itu, banyak pembaca awam yang merasa bahwa buku NKCTHI tidak memberikan efek apapun pada mereka, tidak seperti pembaca lain yang bisa 'emosional' ketika membacanya hingga menangis. Dan banyak juga yang beranggapan, dengan harga yang terbilang cukup mahal, namun waktu yang diperlukan untuk membaca hanya sebentar, membuat sebagian pembaca merasa 'kurang puas' untuk dapat menikmatinya. Karena memang buku NKCTHI hanya berisi kutipan-kutipan pendek sehingga tidak membutuhkan waktu lama untuk membacanya, dan di dominasi dengan ilustrasi-ilustrasi simpel dengan tone warna yang soft. 
Yulianti Mayank Sari, Riama Maslan Sihombing, Irma Damajanti, Buku Pengembangan Diri sebagai Media Art as Therapy (Studi Kasus: Buku "Nanti KitaCerita Tentang Hari Ini”)

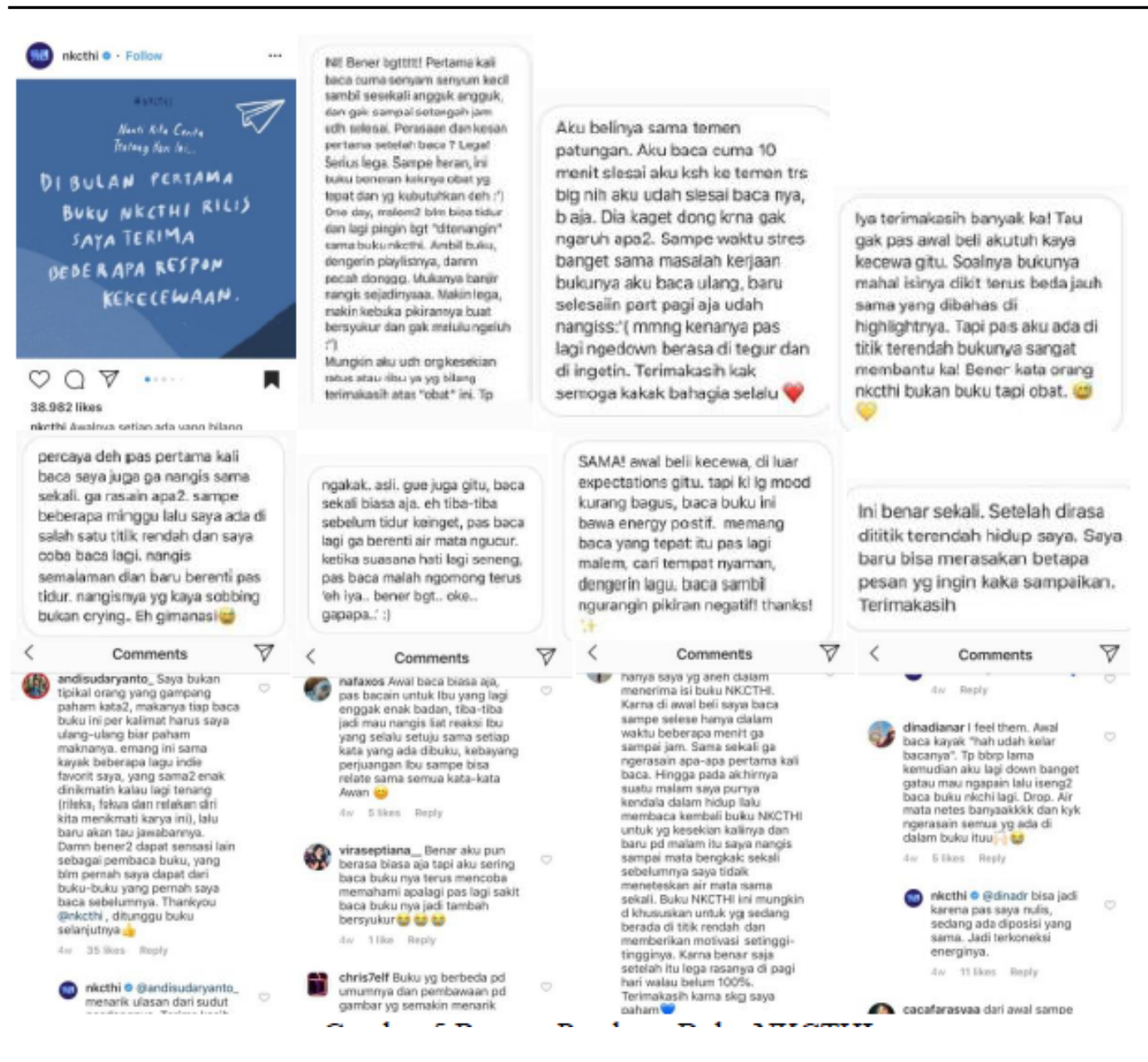

Gambar 5 Respon Pembaca Buku NKCTHI

Seperti yang tertulis pada akun instagram@nkcthi bahwa pada bulan awal terbitnya buku NKCTHI, mereka mendapatkan respon kekecewaan. Lalu setelah itu banyak yang berkomentar bahwa pada saat pertama kali membaca buku NKCTHI memang tidak memiliki efek apapun atau bisa dibilang 'biasa aja'. Namun setelah dibaca lagi pada saat 'mood' yang kurang bagus atau sebelum tidur, ada yang bereaksi bahwa buku ini memberikan energi positif, kebanyakan dari mereka sangat emosional hingga menangis sejadinya, dan hal tersebut membuat efek lega setelahnya. Ternyata buku ini dapat berfungsi seperti obat, tidak memiliki efek apapun pada saat 'sehat' namun bereaksi pada saat 'sakit' seperti pada saat titik terendah dalam hidup atau saat 38 mengalami banyak tekanan / stres. Buku ini baru bekerja untuk 'menyembuhkan', sebagai pengingat kepada manusia dalam segala permasalahan yang biasa dialami sehari-hari. Karena untuk dibaca pertama kali, belum tentu maksud dari penulis bisa langsung dipahami dan diterima oleh pembaca. Ada yang memerlukan waktu sebentar untuk memahami, ada yang butuh waktu berulang kali agar paham, dan ada yang membutuhkan waktu yang 'tepat' untuk paham. Karena setiap interpretasi pembaca tidak dapat disamakan satu dengan yang lainnya. 
Vol. 7, No. 1, Oktober 2019

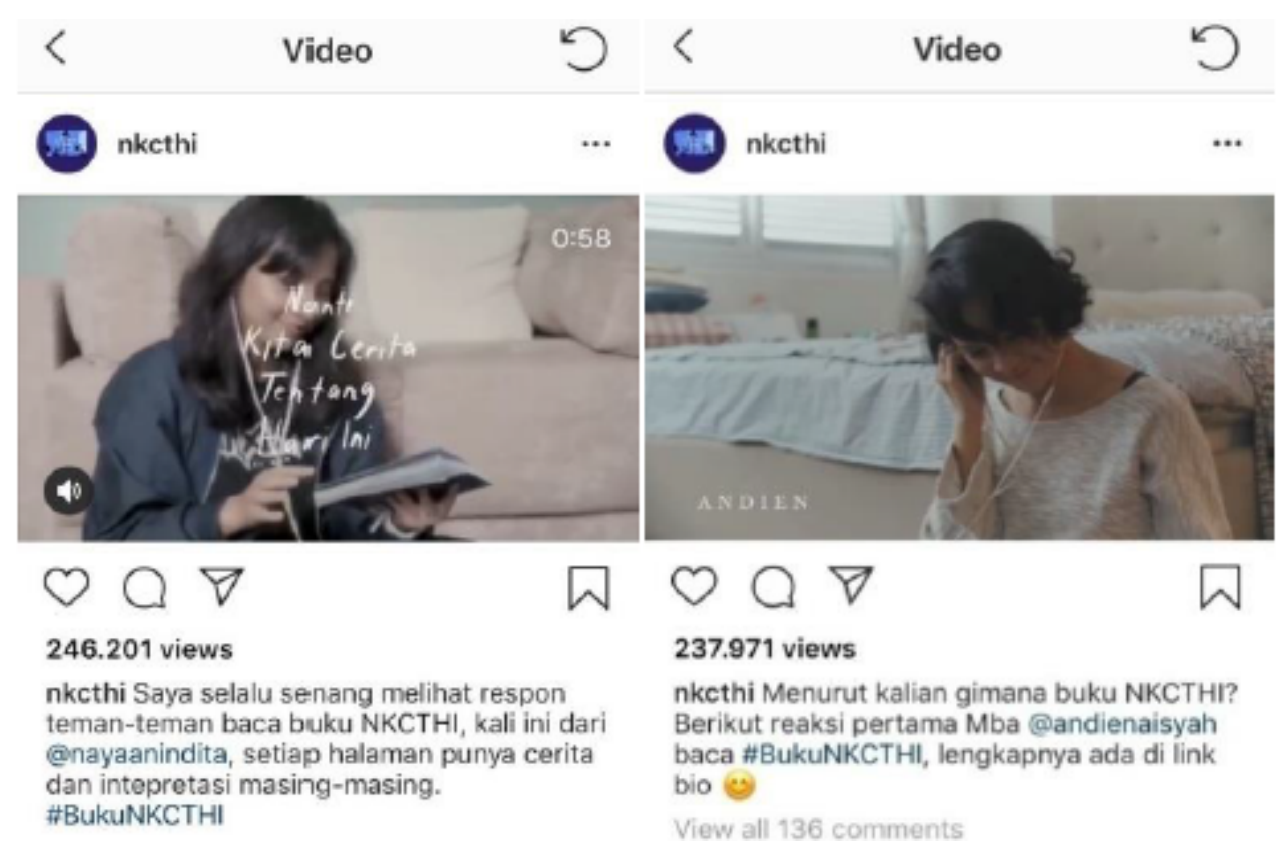

Gambar 6 Respon Public Figure pada Buku NKCTHI

Seperti salah satu ulasan pembaca dari situs www.goodreads.com yang menikmati penyajian sharing session di instagram @nkcthi dengan pemecahan masalahnya. Namun ketika membaca bukunya, responnya biasa saja dan tidak 'merasakan' seperti kebanyakan orang. Dinilai tidak sesuai ekspektasi karena hanya berisi kumpulan kutipan-kutipan singkat. Namun pembaca ini menyimpulkan bahwa, setiap individu memiliki cara penyaluran emosi yang berbeda-beda dan katarsisnya, tidak semua orang menikmati quotes untuk pelipur lara, dan harus memiliki hubungan atau keterikatan masalah dengan kutipan yang ada di buku, jika sedang 'baik-baik saja' dan tidak butuh nasihat, buku NKCTHI tidak memiliki pengaruh apapun. Dan semua kembali lagi pada selera tiap individu yang berbeda. Namun dari segi visual, kebanyakan pembaca sangat menyukai ilustrasinya yang simpel dan pemilihan warna yang dinilai 'eye catching' walaupun tanpa menggunakan warna-warna yang mencolok.

\subsection{Buku NKCTHI sebagai Art as Ther-} apy

Dari berbagai respon pembaca buku NKCTHI yang beragam, dapat dihubungkan dengan aspek terapeutik dalam seni oleh pendekatan teori Alain de Botton. Efek terapeutik tersebut merupakan aspek-aspek yang menjadi fungsi utama dalam seni, yaitu remembering, hope, sorrow, rebalancing, self understanding, dan growth. Fungsi terapi seni tersebut akan dikaitakan dengan hasil analisis buku NKCTHI, yaitu:

\section{Remembering}

Dalam buku NKCTHI, tujuan Awan menulis surat-surat berupa kutipan pengalaman dan pelajaran yang telah ia lalui dalam hidupnya, adalah untuk mengingatkan dirinya sendiri di masa depan. Karena perbedaan sudut pandang yang makin berlawanan dan waktu yang dimiliki untuk bercerita semakin sedikit antara Awan dan ibunya, memberikan kekhawatiran kepada Awan bahwa kelak ia akan melakukan hal yang sama seperti ibunya, kepada 
Yulianti Mayank Sari, Riama Maslan Sihombing, Irma Damajanti, Buku Pengembangan Diri sebagai Media Art as Therapy (Studi Kasus: Buku "Nanti KitaCerita Tentang Hari Ini")

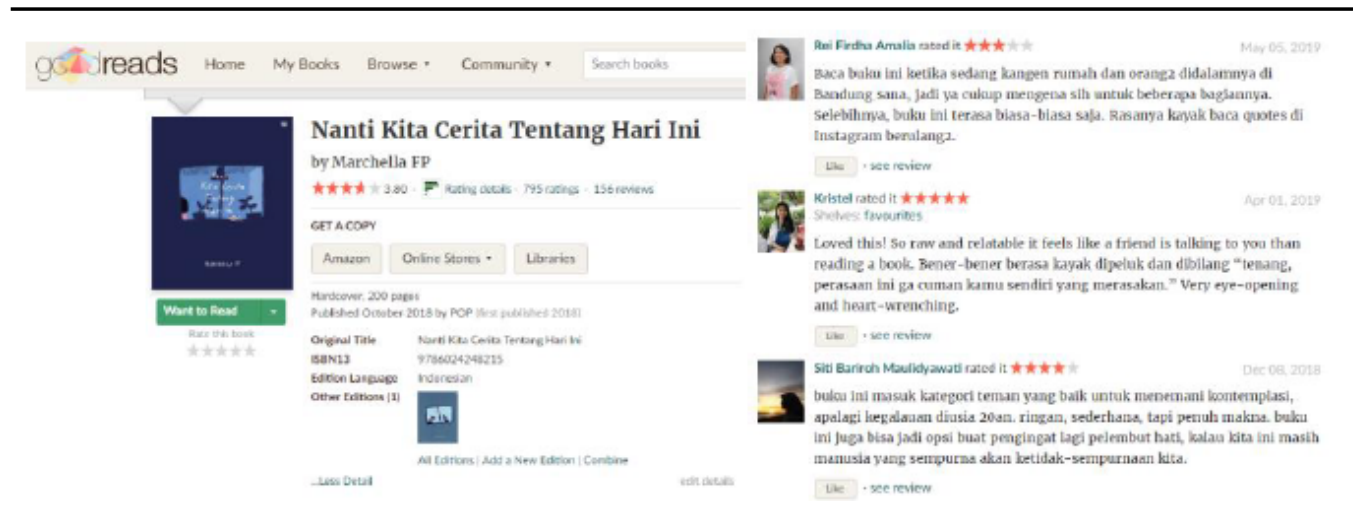

Gambar 7 Respon Pembaca Buku NKCTHI Website www.goodreads.com

anaknya di masa depan. Ketika ibunya menginginkan Awan menjadi matahari, Awan hanya ingin menjadi bohlam, yang dapat menerangi ruangan kecil dan menghangatkan seisi ruang. Awan takut melupakan apa yang membentuk dirinya, segala perasaan dan pemikirannya di kala muda, sehingga mengirimkan surat untuk dirinya dan anaknya di masa depan sebagai pengingat, jika kelak anaknya dewasa dan sudut pandang mereka mulai berlawanan. ilustrasi yang sederhana dengan goresan yang seakan amatir, mengingatkan kita pada gambar masa kanak-kanak, sehingga menimbulkan kedekatan emosi antara pembaca dan pesan dalam buku tersebut. Namun karena komposisi layout, pemilihan tone warna dan tekstur kertas yang tepat membuat keseluruhan aspek visual tersebut harmonis, atau enak untuk dilihat. Dengan gambar yang sederhana banyak sekali pembaca yang menyukainya, bahkan visual tersebut dapat diterima dari kalangan anak-anak, remaja, hingga dewasa.

\section{Hope}

Komentar pembaca buku NKCTHI menyebutkan bahwa isi konten buku tersebut memotivasi dan kalimat positif itu menular. Respon dari pembaca di media sosial yang sangat emosional, bahwa konten buku NKCTHI sangat relevan dalam kehidupan sehari-hari memberikan harapan pada banyak orang bahwa kesedihan adalah hal yang biasa, manusia perlu bangkit untuk melanjutkan hidup. Pada dasarnya manusia membutuhkan semangat, sebuah harapan yang terkadang sulit ditemukan karena terlalu fokus pada diri sendiri. Seperti salah satu kutipan dalam buku NKCTHI: 'Suatu hari ada rasa pahit hadir di hidupmu. Tidak apa-apa. Obat juga pahit, banyak yang sehat karenanya. Mungkin itu cara sang pencipta menyembuhkan'.

\section{Sorrow}

Banyak sekali pembaca buku NKCTHI yang merasa terhubung dengan konten buku tersebut karena berada di posisi dan kondisi yang sama dengan apa yang digambarkan isi buku, karena konten tersebut sangat relevan dengan permasalahan dalam kehidupan sehari-hari. Seperti permasalahan keluarga, persahabatan, karir dan cita-cita. Banyak pembaca yang merasa bahwa mereka tidak sendirian, kesulitan-kesulitan dan masalah yang dihadapi adalah sebuah peristiwa yang dialami banyak orang juga, sehingga memudahkan mereka dalam menerima dan bangkit dari kesulitan dan penderitaan yang dihadapi. Aspek sorrow ini berhubungan dengan aspek sebelumnya, yaitu hope. Harapan ada karena terdapat titik terang atau jalan dalam sebuah permaalahan. 
Vol. 7, No. 1, Oktober 2019

4. Rebalancing

Banyak orang membutuhkan sebuah 'pelarian' untuk mengurangi tekanantekanan yang dihadapi dalam kehidupan sehari-hari. Setelah membaca buku NKCTHI, beberapa pembaca buku NKCTHI mengatakan merasa lebih rileks dan merasa ditenangkan. Sehingga buku tersebut berpengaruh untuk dibaca pada saat emosi sedang tidak stabil, karena mampu menyeimbangkan emosi yang sebelumnya naik turun. Kalimat dalam buku NKCTHI merupakan pengingat bagi pembacanya sehingga menjadi pribadi yang lebih baik lagi.

\section{Self-Understanding}

Mayoritas pembaca buku NKCTHI merasa relevan terhadap isi konten buku tersebut, banyak hal yang baru disadari setelah membacanya. Banyaknya kesamaan yang dirasakan dalam kutipan buku NKCTHI, seseorang menjadi mampu mengenali siapa dirinya dan lebih memahami diri sendiri. Seperti salah satu kutipan dalam buku NKCTHI: 'Terasa panjang perjalanan pulang, langit biru menuju abu-abu. Seperempat sisa energi, beri ruang untuk mengulang'.

\section{Growth}

Dari hasil observasi pembaca buku NKCTHI menyebutkan bahwa, sudut pandang yang diberikan dalam buku membukakan sudut pandang lain sehingga memberikan pandangan baru kepada pembaca. Banyak hal baru yang didapat yang tidak terpikirkan sebelumnya. Terdapat pesan moral dan pelajaran hidup yang dapat diambil hikmahnya dari konten buku tersebut.

\section{Appreciation}

Buku NKCTHI mengajarkan kita untuk menerima keadaan, menjalani dan mensyukurinya. Isi buku tersebut bukan bercerita tentang hal-hal besar yang harus dicapai dalam hidup, tetapi mengingatkan kita pada hal-hal kecil yang seringkali terlewatkan. 'Kadang cukup itu lebih dari cukup'. Buku NKCTHI mengajarkan kita untuk menghargai diri sendiri dan hal-hal kecil yang terjadi dalam hidup.

\section{Kesimpulan}

Bidang seni rupa dan desain tidak hanya sebatas pada aspek estetik, bila digali lebih dalam sebuah karya seni rupa dan desain memiliki manfaat pada aspek psikologis. Filsuf Alain de Botton mengatakan bahwa seni memiliki efek terapeutik dengan memanfaatkan kelemahan psikologis manusia dan menjadikannya sebagai kekuatan yang bermanfaat pada kesehatan mentalnya. Buku pengembangan diri atau self help book merupakan cara mudah untuk mendapatkan efek terapeutik dalam seni. Buku pengembangan diri bertujuan untuk membentuk pola pikir dan memberikan solusi pada suatu permasalahan, buku tersebut dibuat berdasarkan fakta dan pengalaman. Salah satu buku pengembangan diri bergambar best seller adalah 'Nanti Kita Cerita Tentang Hari Ini' atau disingkat 'NKCTHI' karya Marchella F.P. dengan penjualan 77.000 eksemplar hingga bulan Februari 2019. Buku ini merupakan flash fiction yang dibuat berdasarkan kumpulan pengalaman banyak orang dengan penggalan kutipan-kutipan yang dekat dengan kehidupan sehari-hari. Dengan berbagai respon yang telah di observasi di berbagai platform online, dapat disimpulkan bahwa buku NKCTHI memenuhi aspek-aspek sebagai media art as therapy. Hal ini dibuktikan dengan mengaitkan teori Alain de Botton mengenai 7 fungsi utama dalam seni yang dimiliki pada buku NKCTHI, yaitu remembering, hope, sorrow, rebalancing, self understanding, dan growth yang telah dijabarkan dalam hasil dan pembahasan. Walaupun dalam tujuh aspek tersebut, buku NKCTHI hanya memiliki beberapa aspek dominan yang perlu diteliti lebih lanjut 
Yulianti Mayank Sari, Riama Maslan Sihombing, Irma Damajanti, Buku Pengembangan Diri sebagai Media Art as Therapy (Studi Kasus: Buku "Nanti KitaCerita Tentang Hari Ini")

dengan responden yang sudah ditentukan.

Namun pada penelitian ini dibatasi dengan studi literatur dan data penelitian yang dihubungkan dengan teori yang digunakan. Secara garis besar, penelitian ini ingin menyampaikan bahwa tujuan dan manfaat dari seni pada aspek psikologis sangat besar dan dapat dijadikan acuan dalam melakukan perancangan sebuah karya seni dan desain yang dapat menyentuh dan dikenang seperti buku NKCTHI ini. 
Vol. 7, No. 1, Oktober 2019

\section{Daftar Pustaka}

Botton, Alain., dan Armstrong. 2013. Art as Therapy. London: Phaidon

Marchella, P. 2018. Nanti Kita Cerita Tentang Hari Ini. Jakarta: Kepustakaan Populer Gramedia

Sarwono, J., dan Lubis 2007. Metode Riset untuk Desain Komunikasi Visual. Yogyakarta: Penerbit ANDI

6 Fakta yang Mengiringi Larisnya Nanti Kita Cerita Tentang Hari Ini, Penulis Fransisca Desfourina, data diperoleh melalui situs internet: https://www.gramedia.com/blog/faktadi-balik-larisnya-buku-nanti-kita-cerita-tentang-hari-ini-marchella-fp/\#gref.

Diunduh pada tanggal 31 Oktober 2018.

Book Review: Nanti Kita Cerita Tentang Hari Ini Karya Marchella FP, Penulis Sintia Astarina, data diperoleh melalui situs internet: https://www.sintiaastarina.com/nanti-kitacerita-tentang-hari-ini-marchella-fp/. Diunduh pada tanggal 1 November 2018.

Instagram Nanti Kita Cerita Tentang Hari Ini, data diperoleh melalui situs internet: https:// www.instagram.com/nkcthi/?hl=id Diunduh pada tanggal 20 Januari 2019.

Review Nanti Kita Cerita Tentang Hari Ini by Marchella FP, data diperoleh melalui situs internet:https://www.goodreads.com/book/show/42435393-nanti-kita-cerita-tentang-hariini Diunduh pada tanggal 20 Juli 2019.

YouTube Nanti Kita Cerita Tentang Hari Ini, data diperoleh melalui situs internet: https:// www.youtube.com/channel/UC0i3VDgRlxLBZIMSSNSbw-Q Diunduh pada tanggal 20 Januari 2019. 